Insight Botany 1 (3): 28-38, 2011

ISSN 2044-8767 / DOI: 10.5567/BOTANY-IK.2011.28.38

(C) 2011 Insight Knowledge, UK

\title{
Anatomical Basis for Optimal Use of Water for Maintenance of Some Mesophytic Plants
}

\author{
A.A. Abdulrahaman and F.A. Oladele \\ Department of Plant Biology, University of Ilorin, Ilorin, Nigeria
}

\begin{abstract}
Background: One of the strategies for mitigation of global warming and climate change is growing of more green plants. This translates to the need of water for their sustenance and against the backdrop of global water crisis; there is the need for conservation of water and prevention or minimization of water wastage in irrigation. One of the ways to reduce water wastage is lowering the frequency of watering. Materials and methods: In this study, 3 mesophytic plants namely Jatropha curcas, Jatropha gossypifolia and Canna indica were subjected to 4 watering frequencies i.e. daily weekly, biweekly and monthly under 5 varying soil moisture contents namely $1.25,2.25,5,10$ and $20 \%$. This was to determine the anatomical adaptations of the species to water stress with a view to determining the low watering regimes that can sustain them. Results: Jatropha curcas was the most tolerant of water stress with capacity to survive and thrive at daily watering regime of 25 to $100 \mathrm{cc}$. This was possibly attributable to presence of trichome density and low transpiration rate of $4.53 \times 10^{-9} \mathrm{~mol} / \mathrm{m}^{2} / \mathrm{sec}$ (abaxial) and $3.77 \times 10^{-9} \mathrm{~mol} / \mathrm{m}^{2} / \mathrm{sec}$ (adaxial). Canna indica was the least tolerant of water stress possibly due to absence of trichomes and high transpiration rate of $4.72 \times 10^{-5} \mathrm{~mol} / \mathrm{m}^{2} / \mathrm{sec}$ (abaxial) and $3.88 \times 10-5 \mathrm{~mol} / \mathrm{m} / \mathrm{sec}$ (adaxial). Conclusion: These 3 species which have high frequency of paracytic and brachyparacytic stomata are potential candidates for revegetation and landscape exercises with minimal use of water. Recommended daily watering regimes are 25 to $100 \mathrm{cc}$ for Jatropha curcas, $200 \mathrm{cc}$ for J. gossypifolia and $400 \mathrm{cc}$ for Canna indica.
\end{abstract}

Key words: Global warming, climate change, conservation of water water stress, stomatal complex types, transpiration rates

\section{INTRODUCTION}

By definition, plant WUE is determined by both photosynthesis and transpiration. Increasing photosynthesis and/or decreasing transpiration would elevate plant WUE. Stomata play a crucial role in both processes and hold the keys to increase plant WUE and hence bio-water saving. The physiological and molecular basis of bio-water saving is complicated and is highly linked to drought tolerance mechanisms (Chaves and Oliveira, 2004). The efficient water use by plants plays a predominant role in the areas where the water is a limiting factor for production. In addition wUE could be used as selection criterion, to improve yield in a dry environment (Tardieu, 1997). The estimation of the WUE can be based either on the evapotranspiration or on plant transpiration; however, the transpiration based WUE provides a more useful indication of plant performance (Davies and Pereira, 1992; Lazaridou and Koutroubas, 2004).

Much of water taken up by plants is released through transpiration (Burghardt and Riederer, 2003; Metselaar and Lier, 2007). Transpiration is considered as a necessary evil. This is because transpiration pull is believed to aid absorption of water and nutrients from the soil via the root hairs to all parts of the plant. It also cools the temperature of the plant during the hot weather. Water from the soil carrying dissolved minerals enters a plant through the roots and flows along microscopic xylem tubes up the stem or trunk to the leaves. This brings the water and minerals to the places where they are required. To maintain the vital flow water evaporates as invisible water vapour from the leaves into the air. As water evaporates from the leaves, more comes into the root to replace it. In fact water is pulled in a continuous stream through the plant, from root to leaf, by capillary action - a wick or suction effect, known as transpiration tension. Much of the water passes through the plant and into the air without being taken into the plant's cells. However, transpiration is one of the major causes of water stress in plants. Rate at which plants loss water to the atmosphere differs but, in most plants 90 to $450 \mathrm{~kg}$ of water are transpired (The Columbia Encyclopedia, 2004). The US Environmental Protection Agency (EPA) estimates that an acre of corn transpired 4,000 gallons of water each day. On a hot day, the leaves of a large oak can lose $200 \mathrm{~L}$ ( 53 gallons) in an hour by transpiration; cottonwood trees

Corresponding Author: A.A. Abdulrahaman, Department of Plant Biology, University of Ilorin, Ilorin, Nigeria Tel: +2348033897870 
will lose 100 gallons of water per hour during hot desert days. One hectare of tropical forest releases 200, 000 litres (53, 000 gallons) of water daily into the atmosphere. This is 20 times the rate of direct evaporation from a lake or sea. It has been calculated that nearly two thirds $(2 / 3)$ of the water in the water cycle has passed through plants. This is to maintain $99 \%$ atmospheric water balance. Plants also participate in soil water circulation by transpiration (Wu et al., 2005).

However, there are no clear cut amount of water requirements and frequencies of watering to be used for irrigating most plants in the literature. Terms such as constantly moist, allow to dry between watering, moderately moist, frequent watering, infrequent watering water in a week or weeks or a month and tolerant to drought are often used. These terms can be confusing. They are not precise and can be interpreted in many ways which result in plant injury. Few plants are able to grow in constantly soggy soil. Few plants can last long in soil which has dried out completely. Between these two extremes is plenty of room for watering mistakes.

Studies describing how stomatal features (e.g., stomatal density, stomatal index, stomatal size) help plants to respond to different water stresses, highlighting relationships with gas exchange especially transpiration are rather few. In this study, therefore three mesophytic plants namely Jatropha curcas, Jatropha gossypifolia and Canna indica were selected based on their individual values which are credentials for choosing them. J. gossypifolia is a bushy, gregarious shrub of about $1.8 \mathrm{~m}$ in height. The leaves are about 3-5 lobed, palmately. The flowers are red-crimson or purple in corymbs with greenish seeds in capsule (Morton, 1981; Olowokudejo, 1993; Oudhia, 2001). This plant is believed to originate from Central to South America and Caribbean. Different parts of $J$. gossypifolia are used in different countries in many ways. The leaves of $J$. gossypifolia are used for intermittent fevers, carbuncles eczema, itches and sores on the tongues of babies, swollen mammae, stomachache and venereal diseases (Balee, 1994). The leaf decoction is used for bathing wounds (Morton, 1981). The bark contains the alkaloid jatrophine and a lignin (jatroiden) is found in its stem. Seeds are emetic, purgative and used for body pain. Plant is antibiotic, insecticidal and used for toothache and as blood purifier (Balee, 1994; Oduola et al., 2005). The stem latex of J. gossypifolia is routinely used in southern Nigeria by herbalists, rural dwellers and some people in urban centers to stop bleeding from nose, gum and skin (Oduola et al., 2005).

$J$. curcas is a multipurpose plant with many attributes and considerable potential. It is a tropical plant that can be grown in low to high rainfall areas and can be used to reclaim land, as a hedge and/or as a commercial crop. Thus, growing it could provide employment, improve the environment and enhance the quality of rural life (Openshaw, 2000). J. curcas, the physic nut, is frequently grown in tropical and subtropical areas throughout the world, as an ornamental plant and occasionally for medicinal purposes. The physic nut as typical of many members of Euphorbiaceae, has a caustic, milky sap and toxic seed. There apparently are varieties in the toxicity of the seeds, some varieties are considered toxic and others are harmless. The toxic and harmless varieties cannot be distinguished visually. $J$. curcas is an annual shrub up to about $5 \mathrm{~m}$ tall. Stems are thick, green, glabrous, mostly herbaceous or somewhat succulent, becoming woody at the base. Leaves are alternate, long petioled, palmately veined, cordate to truncate at the base, about $1.50 \mathrm{~m}$ wide, margin irregular or with 3-5 shallow lobes, points acute or obtuse. Flowers are small, yellow, unisexual, in clusters in leaf axils, mostly hidden in foliage. Fruit an ovoid, 3-locular capsule, at first green and fleshy, becoming brownish or almost black and dry at maturity, containing up to 3 black seeds about $20 \mathrm{~mm}$ long. Usefulness of this plant is enormous and cut across almost all sectors. These include: young leaves may be safely eaten, steamed stewed; pounded leaves are applied near horses' eyes to repel flies in India; $J$. curcas leaves help in dressing the wound; flowers of the species are listed as a honey plant; nuts are sometimes roasted and eaten, although they are purgative; nuts can be burned like candlenuts when strung on grass; also nuts are used as contraceptive in south Sudan; seeds are also used as a contraceptive in south Sudan; seed can be used as bio-diesel for any diesel engine without modification; the oil obtained from seeds has been for illumination, soap, candles, cooking, in engines, varnishes, pest control and medicinal for skin diseases, as purgative; pounded seeds are used in tanning; press cake of $J$. curcas becomes organic fertilizer and soil improver; root ashes are used as a salt substitute; root can be used to kill mollusks, has been listed for homicide, piscicide and raticide as well; $J$. curcas roots help in making yellow dye; bark is used as a fish poison; dark blue dye and wax can be produced from the bark of the $J$. curcas plants; latex strongly inhibits the watermelon mosaic virus; sap stains linen. Sometimes used for marking; Mexicans grow the shrub as a host for the lac insect which is used in medicine as hepatoprotective and antiobesity drug (Gubitz et al., 1999; Openshaw, 2000; Pramanik, 2003). In country such as India, J. curcas is extensively exploited in afforestation to check desertification. Government is seriously spending on its propagation and people are encouraged to participate in this laudable programme. Aside checking desert 
encroachment, some pilot biodiesel plants are built to produce biodiesel oil from $J$. curcas seeds for moving engines.

C. indica is a robust perennial herb up to 3 feet $(1 \mathrm{~m})$ tall that grows from a thick, branching, underground rhizome or seed. The large green leaves taper into slender petioles that formed sheath around the main stem. Unlike the numerous cultivated varieties of domesticated canna (Canna $x$ generalis) with showy yellow, orange, pink or red blossoms, the flowers of $C$. indica are much smaller and typically only come in red. Cannas (of Cannaceae family) are popularly cultivated flowers in tropic and temperate gardens because they produce some of the world's most beautiful and exotic blossoms. The unique flower has three small greenish sepals (appearing like bracts), three green coloured petals and five (or fewer) very showy petaloid false-stamens called staminodia. The colourful staminodia form the main showy part of the blossom that people associate with petal. Very hard, BBlike seeds are produced in bumpy, papery capsules after the blossoms have wiltered away. Because of their dense woody seed coat, the seeds need to be scarified and soaked in water prior to germination. C. indica was originally named by the eighteenth century Swedish botanist Carl Linne, usually known by his Latinized name Carolus linnaeus apparently thought this was native to India hence, the specific epithet of indica. C. indica is an ornamental plant by all standards; it is highly appealing to eyes. Its rhizomes are eaten after cooking; leaves are used for wrapping material; the hard black seeds are made into necklace and rosaries and are used in rattles and percussion instruments

The objectives of this study are to determine the responses of stomatal features (and other epidermal features) to different water status and to develop the relationship of stomatal features with transpiration rate of the three mesophytic plants.

\section{MATERIALS AND METHODS}

Five seeds each of $J$. curcas, $J$. gossypifolia and five stem cuttings of $C$. indica were placed in 5 sets of plastic pots, filled with loamy soils of 5 regimes of moisture contents namely $1.25,2.5,5,10$ and $20 \%$ (Walter, 1979). A total of 300 pots per species were maintained in a greenhouse at University of Ilorin, Ilorin, Nigeria. The plants in soils of each moisture content were subjected to 4 regimes of watering namely daily weekly, biweekly and monthly (Table 1,2). The experiments were conducted for a period of 6 months.

Times (days) taken for emergence of leaves were noted. Mature leaves were subjected to determination of
Table 1: Soil and water regimes used for raising the study materials

\begin{tabular}{lcc}
\hline Soil $(\mathrm{g})$ & Water $\left(\mathrm{mL}^{-1}\right)$ & Moisture content (Water regime) $(\%)$ \\
\hline 1600 & 400 & 20 \\
1800 & 200 & 10 \\
1900 & 100 & 5 \\
1975 & 25 & 1.25 \\
\hline
\end{tabular}

Table 2: Watering frequencies and regimes used for raising seedlings of the study materials

\begin{tabular}{lc}
\hline Watering intervals & Soil moisture content (\%) \\
\hline Daily & 1.25 \\
& 2.5 \\
& 5 \\
& 10 \\
Weekly & 20 \\
& 1.25 \\
& 2.5 \\
Biweekly & 5 \\
& 10 \\
& 20 \\
& 1.25 \\
Monthly & 2.5 \\
& 5 \\
& 10 \\
& 20 \\
& 1.25 \\
& 2.5 \\
& 5 \\
& 10 \\
\end{tabular}

leaf area (Franco, 1939) and of transpiration rate (Obiremi and Oladele, 2001; Dutta, 2003). Leaves were harvested for anatomical study. Leaf cuticles were macerated in concentrated nitric acid or trioxonitrate (v) acid, rinsed in distilled water, stained in $1 \%$ aqueous safranin solution and mounted in dilute glycerine (Dutta, 2003). Parameters on stomata determined were stomatal density, stomatal index and stomatal size (Franco, 1939; Dilcher, 1974) and frequency of each complex type was expressed as percentage occurrence of such complex type based on all occurrences (Obiremi and Oladele, 2001). Index of similarity of leaf surface followed the formula of Philips (1959). Statistical analysis of data consisted of analysis of variance and duncan multiple range test (Bailey, 1995; Duncan, 1955).

\section{RESULTS}

All the 3 species, Jatropha gossypifolia, J. curcas and Canna indica are hypoamphistomatic i.e. having more stomata on the lower surface of leaves than on the upper surface. All the 3 species also have paracytic and brachyparacytic stomatal complex types (i.e., two subsidiary cells per stoma) on both adaxial and abaxial leaf surfaces with 100\% frequency (Fig. 1-3). Thus, because of having the same stomatal complex type(s) on both leaf surfaces, stomatal index of similarity was $100.00 \%$ in $J$. gossypifolia, J. curcas and C. indica. Tomentum of 

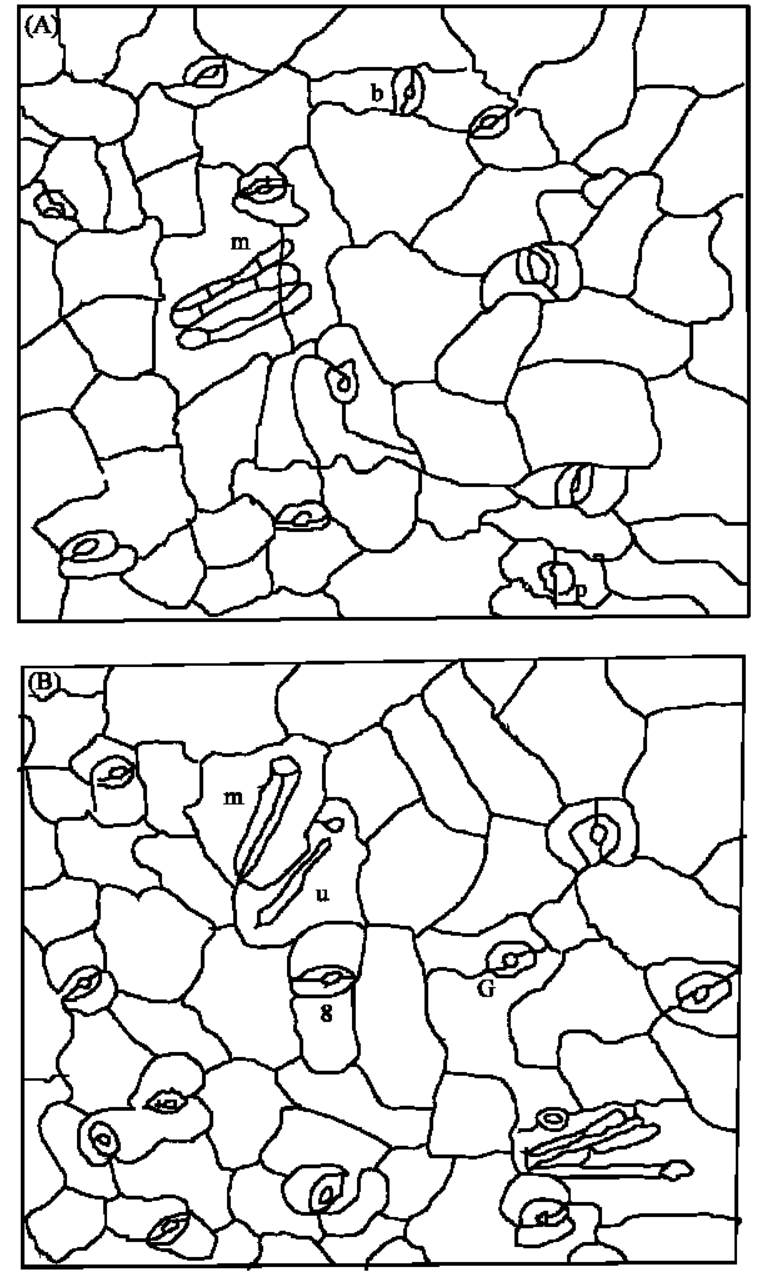

Fig. 1: Surface view of leaf epidermis, abaxial (A) and adaxial (B) of Jatropha gossypifolia propagated with $20 \mathrm{cc}$ daily watering regime showing paracytic (p) and brachyparacytic (b) stomata and unicellular $(\mathrm{u})$ and multicellular $(\mathrm{m})$ trichomes $\mathrm{x} 2000$

trichomes were found in the two species of Jatropha ( $J$. gossypifolia and $J$. curcas) but absent in C. indica. The plants subjected to daily watering regimes survived followed by weekly watering regimes whereas plants at 1.25 and $2.5 \%$ soil moisture contents did not survive. For biweekly and monthly watering, only plants in 10 to $20 \%$ soil moisture contents survived (Table 4). Moreover, Canna indica plants watered monthly did not survive (Table 4, 5).

Four watering regimes taken to be regimes of water stress were: daily at $1.25 \%$ soil moisture content weekly at $1.2,2.5,5$ and $10 \%$, biweekly at $1.2,2.5,5$ and $10 \%$ and monthly at $1.2,2.5,5,10$ and $20 \%$ soil moisture contents.
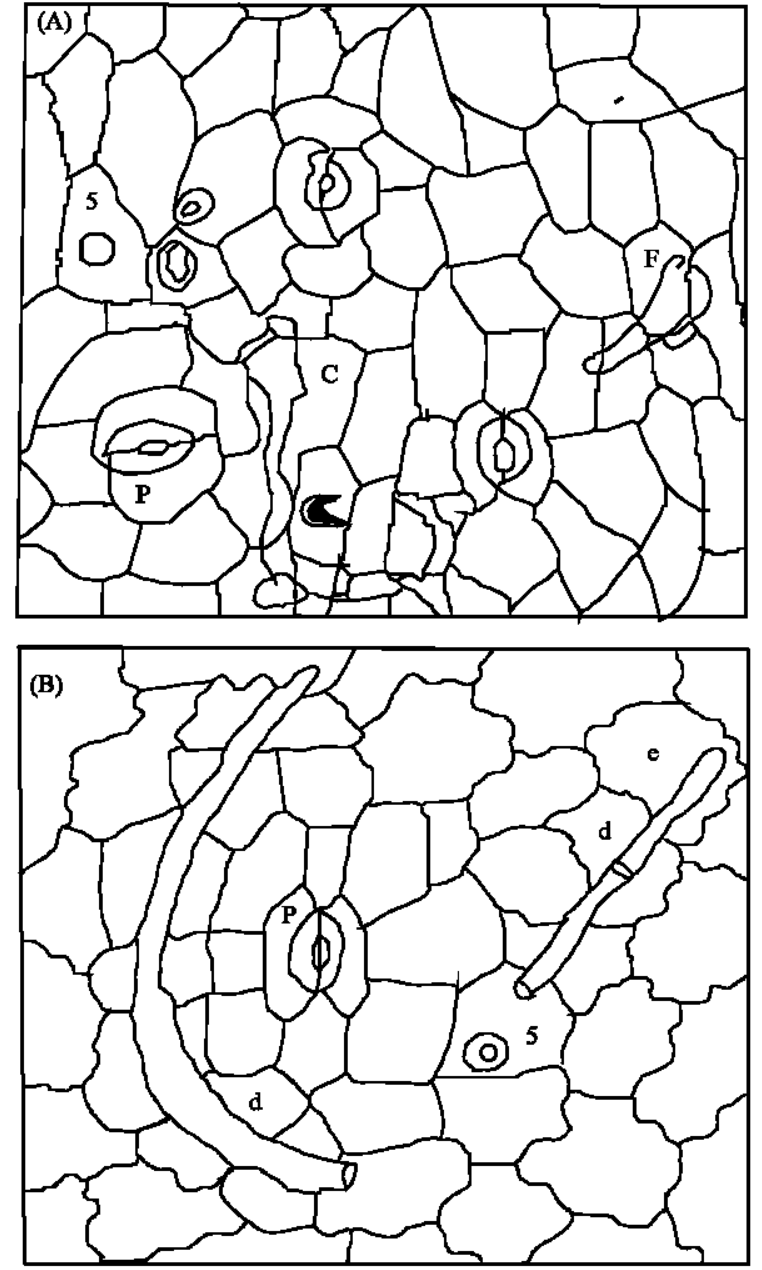

Fig. 2: Surface view of leaf epidermis, abaxial (A) and adaxial (B) of Jatropha curcas propagated with 20 $\mathrm{cc}$ monthly watering regime showing paracytic (p) stomata and long-branched multicellular (c), longunbranched unicellular (d), long-unbranched multicellular (e), short unicellular and scale (s) trichomes $\mathrm{x} 2000$

Based on these regimes, Jatropha curcas was the most tolerant of water stress with capacity to survive and thrive at daily watering regimes of 25 to $400 \mathrm{cc}$. The anatomical features possibly responsible for this capacity are namely low stomatal density, high trichome density and low transpiration rates (Table 3-5). Canna indica, on the other hand was the least tolerant because of high stomatal density, absence of trichomes and high transpiration rates (Table 3-5). This species therefore, requires daily watering regimes, or $200 \mathrm{cc}$ weekly watering regimes.

While water stress caused reduction in the size of stomata, there was no definite pattern of effects on the 

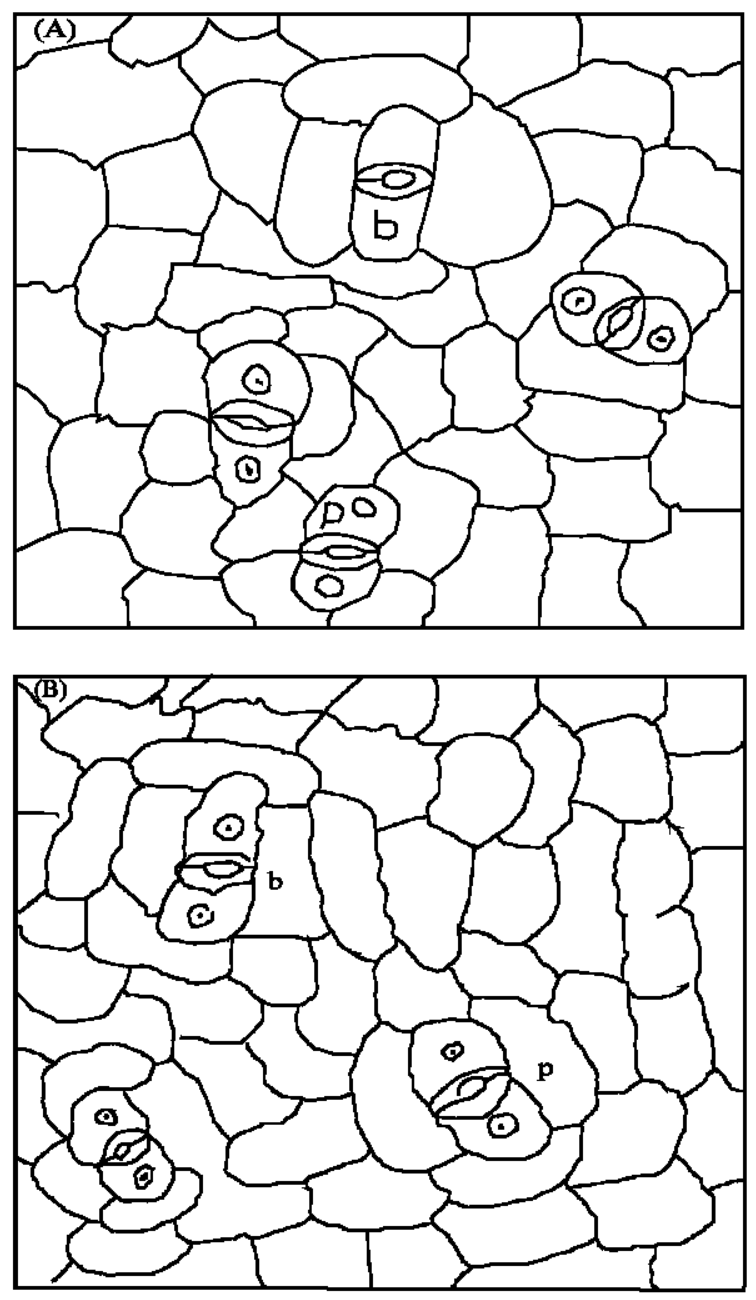

Fig. 3: Surface view of leaf epidermis, abaxial (A) and adaxial (B) of Canna indica propagated with 2.5 $\mathrm{cc}$ daily watering regime showing paracytic (p) and brachyparacytic (b) stomata $\mathrm{x} 1600$

density of stomata (Table 4, 5). Water-stress led to reduction in the rate of transpiration especially in J. curcas (Table 4, 5).

Based on the anatomical indices for watering frequency observed in the three mesophytic plant species studied, some features are thus ascribed to each of these species for better performance with reference to water stress condition. Therefore, some leaf epidermal features that may thus be of relevance to the water economy (i.e., features that may serve as indices for frequency of watering) the three mesophytic plant species are as follows:

\section{Jatropha curcas:}

- High frequency of paracytic and brachyparacytic stomata
- Hypoamphistomatic nature of leaves

- Presence of tomentum of trichomes on leaf surfaces

Recommendation: Daily watering regime of $100 \mathrm{cc}$ should be used to propagate $J$. curcas.

\section{Jatropha gossypifolia:}

- High frequency of paracytic and brachyparacytic stomata

- Hypoamphistomatic nature of leaves

- Presence of tomentum of trichomes on the leaf surfaces

Recommendation: Daily watering regime of $200 \mathrm{cc}$ is a better option for raising $J$. gossypifolia.

\section{Canna indica:}

- High frequency of paracytic and brachyparacytic stomata

- Hypoamphistomatic nature of leaves

Recommendation: Daily watering regime of $100 \mathrm{cc}$ should be used to propagate $C$. indica.

These three mesophytic plant species were listed in decreasing order of their stomata to conserve water and increasing order to humidify the atmosphere.

\section{DISCUSSION}

Plant water stress depends on relative rate of water absorption and water loss rather than on soil water supply alone, hence it is safe to assume that a given degree of soil water deficit will be accompanied by an equivalent degree of plant water stress (Klooster and Palmer-Young, 2004; Dunford and Vazquez, 2005). When plant roots are subjected to water stress, ABA (abscisic acid) accumulation may be initiated by a drought-sensing mechanism located in the roots where it can be exported to leaves (Pei and Kuchitsu, 2005), thus reducing water loss by stomatal regulation (Cominelli et al., 2005; Gudesblat et al., 2007). On the other hand, long-term soil drought can also lead to up-regulation of leaf osmotic pressure and lower water potential around the stomata while osmoregulation promotes greater stomatal conductance water vapour under moderate soil drought (Buckley, 2005).

The major benefit alleged to accrue from transpiration is that it is essential for the long-distance transport of mineral ions but the possible interrelation between these two processes has rarely been tested. Tanner and Beevers (2001) reported that transpiration was experimentally dissociated from mineral supply by growing sunflowers (Helianthus annuus) in hydroculture 
Insight Botany 1 (3): 28-38, 2011

Table 3: Transpiration rate of some ornamental plant species propagated with different percentage moisture contents Transpiration rate $\left(\mathrm{mol} / \mathrm{m}^{2} / \mathrm{sec}\right)$

\begin{tabular}{|c|c|c|c|}
\hline \multirow[b]{2}{*}{ Watering regimes $(\%)$} & \\
\hline & Jotropha gossypifolia abaxial adaxial & Jatropha curcasabaxial adaxial & Conna indicaabaxial adaxial \\
\hline \multicolumn{4}{|c|}{ 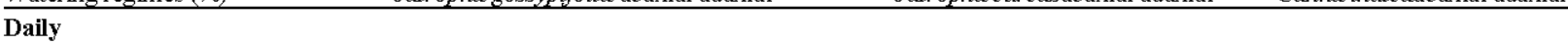 } \\
\hline $1.25^{\circ}$ & $7.00 \times 10^{-6}$ a $5.00 \times 10^{-6 b}$ & $1.20 \times 10^{-8} \mathrm{a} 1.90 \times 10^{-8 b}$ & -. \\
\hline 2.5 & $1.50 \times 10^{-5} \mathrm{a} 3.00 \times 10^{-6 b}$ & $1.03 \times 10^{-8} \mathrm{a} 3.84 \times 10^{-9 b}$ & $3.70 \times 10^{-5} \mathrm{a} 4.03 \times 10^{-5 b}$ \\
\hline 5 & $1.50 \times 10^{-5} \mathrm{a} 3.00 \times 10^{-6 \mathrm{~b}}$ & $4.52 \times 10^{-9} \mathrm{a} 3.77 \times 10^{-9 \mathrm{~b}}$ & $4.72 \times 10^{-5}$ a $3.88 \times 10^{-5 b}$ \\
\hline 10 & $7.00 \times 10^{-6} \mathrm{a} 2.00 \times 10^{-6 \mathrm{~b}}$ & $8.92 \times 10^{-9} \mathrm{a} 7.38 \times 10^{-10 b}$ & $2.48 \times 10^{-4}$ a $7.29 \times 10^{-5 b}$ \\
\hline 20 & $10.46 \times 10^{-5}$ a $8.65 \times 10^{-6 b}$ & $1.09 \times 10^{-9} \mathrm{a} 4.85 \times 10^{-10 b}$ & $5.30 \times 10^{-5}$ a $3.76 \times 10^{-5 b}$ \\
\hline \multicolumn{4}{|l|}{ Weekly } \\
\hline 2.5 & $1.70 \times 10^{-5} 1.12 \times 10^{-5}$ & - - & - - \\
\hline 5 & $1.10 \times 10^{-5} 8.00 \times 10^{-6}$ & .- & - - \\
\hline 10 & $3.82 \times 10^{-6} 2.60 \times 10^{-7}$ & $1.20 \times 10^{-8} 7.21 \times 10^{-9}$ & $1.54 \times 10^{-4} 6.69 \times 10^{-5}$ \\
\hline 20 & $7.00 \times 10^{-6} 3.00 \times 10^{-6}$ & $8.83 \times 10^{-9} 3.91 \times 10^{-9}$ & $6.68 \times 10^{-5} 1.14 \times 10^{-4}$ \\
\hline \multicolumn{4}{|l|}{ Biweekly } \\
\hline 2.5 & - & . - & - - \\
\hline 10 & - - & $1.95 \times 10^{-8} 6.76 \times 10^{-9}$ & $7.59 \times 10^{-5} 1.28 \times 10^{-4}$ \\
\hline 20 & $1.88 \times 10^{-5} 8.99 \times 10^{-6}$ & $1.32 \times 10^{-8} 5.08 \times 10^{-9}$ & $4.41 \times 10^{-5} 1.05 \times 10^{-4}$ \\
\hline \multicolumn{4}{|l|}{ Monthly } \\
\hline 2.5 & - & - - & - \\
\hline 10 & - & $8.69 \times 10^{-9} 5.50 \times 10^{-9}$ & - - \\
\hline 20 & $1.95 \times 10^{-5} 1.14 \times 10^{-5}$ & $8.60 \times 10^{-9} 3.78 \times 10^{-9}$ & - - \\
\hline
\end{tabular}

Means with same letters along the columns are not significantly different at $\mathrm{p}<0.05$

Table 4: Stomatal density in Jatropha gossypifolia, Jatropha curcas and Canna indica raised with different percentage moisture contents

\begin{tabular}{|c|c|c|c|c|}
\hline \multirow[b]{2}{*}{ Watering regimes $(\%)$} & \multirow[b]{2}{*}{ Leaf surface } & \multicolumn{3}{|c|}{ Stomatal density $\left(\mathrm{mm}^{-2}\right)$} \\
\hline & & Jatropha gossypifolia & Jatrophacurcas & Canna indica \\
\hline \multicolumn{5}{|l|}{ Daily } \\
\hline \multirow[t]{2}{*}{1.25} & Abaxial & $16.50^{\mathrm{ab}}$ & $19.67^{a}$ & \\
\hline & Adaxial & $12.22^{c}$ & $3.29^{\mathrm{g}}$ & \\
\hline \multirow[t]{2}{*}{2.5} & Abaxial & $14.25^{b}$ & $8.60^{\circ}$ & $11.13^{\mathrm{d}}$ \\
\hline & Adaxial & $10.81^{\mathrm{d}}$ & $1.00^{\mathrm{h}}$ & $1.67^{\mathrm{g}}$ \\
\hline \multirow[t]{2}{*}{5} & Abaxial & $10.02^{\mathrm{d}}$ & $8.82^{e}$ & $14.00^{c}$ \\
\hline & Adaxial & $06.20^{\circ}$ & $3.00^{\mathrm{g}}$ & $4.17^{\mathrm{e}}$ \\
\hline \multirow[t]{2}{*}{10} & Abaxial & $18.20^{a}$ & $13.80^{\circ}$ & $19.21^{\mathrm{a}}$ \\
\hline & Adaxial & $09.50^{\mathrm{d}}$ & $6.40^{f}$ & $5.00^{e}$ \\
\hline \multirow[t]{2}{*}{20} & Abaxial & $09.67^{\mathrm{d}}$ & $15.00^{b}$ & $12.60^{\mathrm{d}}$ \\
\hline & Adaxial & $04.46^{\circ}$ & $5.00^{f}$ & $2.50^{\mathrm{f}}$ \\
\hline \multicolumn{5}{|l|}{ Weekly } \\
\hline \multirow[t]{2}{*}{5} & Abaxial & $12.01^{\mathrm{c}}$ & & \\
\hline & Adaxial & $10.02^{\mathrm{d}}$ & & \\
\hline \multirow[t]{2}{*}{10} & Abaxial & $13.01^{\mathrm{c}}$ & $10.50^{\mathrm{d}}$ & $17.00^{b}$ \\
\hline & Adaxial & $11.11^{\mathrm{d}}$ & $5.00^{\mathrm{f}}$ & $4.01^{e}$ \\
\hline \multirow[t]{2}{*}{20} & Abaxial & $13.01^{\mathrm{c}}$ & $11.33^{\text {cd }}$ & $18.00^{b}$ \\
\hline & Adaxial & $10.20^{\mathrm{d}}$ & $2.00^{\mathrm{h}}$ & $5.00^{\mathrm{a}}$ \\
\hline \multicolumn{5}{|l|}{ Biweekly } \\
\hline \multirow[t]{2}{*}{10} & Abaxial & & $11.33^{\text {cd }}$ & $10.00^{\mathrm{d}}$ \\
\hline & Adaxial & & $8.50^{e}$ & $2.02^{\mathrm{g}}$ \\
\hline \multirow[t]{2}{*}{20} & Abaxial & $12.16^{c}$ & $6.00^{\mathrm{f}}$ & $15.00^{b c}$ \\
\hline & Adaxial & $13.01^{\mathrm{c}}$ & $3.00^{g}$ & $3.00^{\mathrm{f}}$ \\
\hline \multicolumn{5}{|l|}{ Monthly } \\
\hline \multirow[t]{2}{*}{10} & Abaxial & & $12.56^{\mathrm{cd}}$ & \\
\hline & Adaxial & & $8.25^{e}$ & \\
\hline \multirow[t]{2}{*}{20} & Abaxial & $10.02^{\mathrm{d}}$ & $11.91^{\mathrm{cd}}$ & \\
\hline & Adaxial & $10.01^{\mathrm{d}}$ & $3.60^{\mathrm{g}}$ & \\
\hline
\end{tabular}

Means with same letters along the rows are not significantly different at $p<0.05$

and providing mineral nutrients only during the nights. These plants grew as well as a control group that received nutrients only during the day and transpired 12-15 times more water during the exposure period. It thus appears that convective water transport in the xylem, brought about by the root pressure and the resultant guttation, growth water and Munch's phloem counter flow is in itself sufficient for long-distance mineral supply and that transpiration is not required for this function. However, transpiration is of more water loss than for distribution or 
Insight Botany 1 (3): 28-38, 2011

\begin{tabular}{|c|c|c|c|c|}
\hline \multirow[b]{2}{*}{ Watering regimes $(\%)$} & \multirow[b]{2}{*}{ Leaf surface } & \multicolumn{3}{|l|}{ Stomatal size $(\mu \mathrm{m})$} \\
\hline & & Jatropha gossypifolia & Jatropha curcas & Comna indica \\
\hline \multicolumn{5}{|l|}{ Daily } \\
\hline \multirow[t]{2}{*}{1.25} & Abaxial & $86.00^{\mathrm{a}}$ & $94.64^{b}$ & \\
\hline & Adaxial & $69.75^{\mathrm{c}}$ & $43.90^{\mathrm{f}}$ & \\
\hline \multirow[t]{2}{*}{2.5} & Abaxial & $51.93^{\mathrm{d}}$ & $58.69^{e}$ & $50.01^{\mathrm{d}}$ \\
\hline & Adaxial & $57.00^{\mathrm{d}}$ & $44.42^{\mathrm{f}}$ & $48.60^{\mathrm{d}}$ \\
\hline \multirow[t]{2}{*}{5} & Abaxial & $64.06^{\mathrm{c}}$ & $66.00^{\mathrm{d}}$ & $67.77^{c}$ \\
\hline & Adaxial & $73.37^{\mathrm{bc}}$ & $53.00^{\circ}$ & $66.58^{c}$ \\
\hline \multirow[t]{2}{*}{10} & Abaxial & $53.63^{\mathrm{d}}$ & $70.69^{c}$ & $54.32^{\mathrm{d}}$ \\
\hline & Adaxial & $40.00^{\text {ef }}$ & $109.25^{\mathrm{a}}$ & $92.19^{a}$ \\
\hline \multirow[t]{2}{*}{20} & Abaxial & $54.28^{\mathrm{d}}$ & $53.73^{\mathrm{e}}$ & $83.00^{b}$ \\
\hline & Adaxial & $48.00^{\circ}$ & $100.75^{\mathrm{a}}$ & $82.00^{b}$ \\
\hline \multicolumn{5}{|l|}{ Weekly } \\
\hline \multirow[t]{2}{*}{5} & Abaxial & $67.00^{c}$ & & \\
\hline & Adaxial & $47.69^{\mathrm{e}}$ & & \\
\hline \multirow[t]{2}{*}{10} & Abaxial & $50.44^{\mathrm{d}}$ & $55.09^{\mathrm{e}}$ & $48.01^{\mathrm{d}}$ \\
\hline & Adaxial & $48.00^{e}$ & $101.25^{\mathrm{a}}$ & $47.80^{\mathrm{d}}$ \\
\hline \multirow[t]{2}{*}{20} & Abaxial & $66.00^{c}$ & $57.45^{\mathrm{e}}$ & $45.90^{d}$ \\
\hline & Adaxial & $50.04^{\text {de }}$ & $50.83^{e}$ & $54.00^{d}$ \\
\hline \multicolumn{5}{|l|}{ Biweekly } \\
\hline \multirow[t]{2}{*}{10} & Abaxial & & $79.31^{\mathrm{c}}$ & $54.32^{\mathrm{d}}$ \\
\hline & Adaxial & & $56.84^{e}$ & $56.01^{\mathrm{d}}$ \\
\hline \multirow[t]{2}{*}{20} & Abaxial & $46.00^{e}$ & $53.49^{\mathrm{e}}$ & $58.23^{\mathrm{d}}$ \\
\hline & Adaxial & $56.00^{\mathrm{d}}$ & $129.05^{\mathrm{a}}$ & $62.24^{c}$ \\
\hline \multicolumn{5}{|l|}{ Monthly } \\
\hline \multirow[t]{2}{*}{10} & Abaxial & & & $100.00^{\mathrm{a}}$ \\
\hline & Adaxial & & & $82.25^{c}$ \\
\hline \multirow[t]{2}{*}{20} & Abaxial & $49.45^{\mathrm{e}}$ & & $75.76^{\circ}$ \\
\hline & Adaxial & $23.00^{\mathrm{g}}$ & & $52.25^{\mathrm{e}}$ \\
\hline
\end{tabular}

Means with same letters along the rows are not significantly different at $\mathrm{p}<0.05$

transport of nutrients. Therefore in this present study, rate of water loss or transpiration was found to be useful in monitoring adaptability of each of the study materials to water stress.

In order to determine the comparative rates of transpiration of different species, it is essential that the plants be of the same age without new growth and grown under identical conditions. This is pertinent because plants of different age transpired differently. All the 3 species were propagated and raised in the greenhouse and were subjected to same watering frequencies (Table 3 ) for 6 weeks. Water economy of stomata (Obiremi and Oladele, 2001; Abdulrahaman and Oladele, 2003; Burghardt and Rieder, 2003; Oyeleke et al., 2004; Abdulrahaman and Oladele, 2008; Abdulrahaman, 2009) was greatly demonstrated in this research work where water loss or transpiration occurred only on the leaf surface (s) with presence of stomata. Transpiration occurred on both leaf surfaces in all species studied. This is because the species have stomata on both leaf surfaces. Rate of transpiration was high on the abaxial surface in many seedlings of $C$. indica. This could be due to higher stomatal density and stomatal index on the abaxial surface in the species (Table 3-5). There were significant differences at $\mathrm{p}<0.05$ in the rate of transpiration on abaxial and adaxial leaf surfaces among the six species studied in this work.
Observation through Table 3 showed that transpiration was relatively low on adaxial surfaces of seedlings watered with extreme frequencies of watering regimes of biweekly and monthly than on the abaxial surfaces but, it was relatively high in daily and weekly watering frequencies. This could be described as an adaptation to water stress which could be due to too little water supply in the former or too much water supply in the latter. That is water-stressed plants had lower rate of transpiration on adaxial surface than non water-stressed plants. Reason for these variations was correlated to some morphological and anatomical features especially stomatal anatomy e.g. stomatal complex types, stomatal density, stomatal index and stomatal size possessed by each seedling of various watering frequencies and regimes. The variation in rates of transpiration among the watering frequencies is explained by Awad and Castro (1992) that when the water supply is reduced, the stomatal guard cells lose solutes, increasing their water potential and increasing their abscisic acid (ABA) level thus, causing reduction in their pressure potential and subsequently stomatal closure.

When water is in low supply, the water loss by transpiration may exceed the water absorbed by the root during the day or season (Dawson, 1993). When demand exceeds supply, therefore, perennial plants can regulate the water use found in additional water sources or find 
other ways to conserve water for both metabolism and growth needs. There was great variety of morphological, anatomical and physiological characteristics that either look for adaptation or act as a buffer against the negative water stress effects (Alves de Sena et al., 2007). One of such anatomical characteristics is stomatal features. In water stress conditions, the water vapour loss occurs through parallel ways, the stomatal and cuticular; stomata participation is more significant in the transpiration loss mechanism than cuticles (Larcher, 1980). Stomatal complex types, stomatal densities, indexes and sizes were therefore studied in this present work to monitor their degree of response to water stress conditions. It was therefore observed that these stomatal features had significant influence on the rate of transpiration in the three plant species studied in this work.

Stomata are pores on leaf epidermis for both water and carbon dioxide fluxes that are controlled by two major factors: stomatal behaviour and stomatal density (Wang et al., 2007). Based on the occurrence of stomata on the leaf surfaces, two types of leaves were identified or recognized among the three mesophytic plant species namely amphistomatic and hypoamphistomatic leaves. Amphistomatic leaf type (i.e., having stomata on both leaf surfaces) was present in all the species studied. These particular patterns were also reported by Metcalfe and Chalk (1988) and Qiang et al. (2007). There were more stomata on abaxial surface than on the adaxial surface in majority of seedlings of all the 3 species. This is also an adaptation to water conserving ability of the plants because the adaxial surface is exposed to direct sunlight. Dai et al. (1995) and Kouwenberg et al. (2007) reported that greater reduction of stomata on adaxial surface than on the abaxial surface under 3 and 4 weeks of ultraviolet-B (UVB wavelength $280-320 \mathrm{~nm}$ ) exposure suggests a direct effect of UVB radiation on stomata.

Stomatal density, stomatal index and stomatal size differed from one watering interval and regime to another and from species to species. Stomatal density has been identified to play major role in water use efficiency of plants (Wang et al., 2007). Thus, its numerical strength on the leaf surfaces is essential. Stomatal density is positively correlated with water use efficiency (WUE) (Wang et al., 2007; Xu and Zhou, 2008). In the present research work, stomatal density was generally higher on the abaxial surfaces of all leaves of the studied species than on the adaxial. What is actually responsible for this variation in stomatal density between the leaf abaxial and adaxial surfaces was supposed to be reaction of plants to cut down loss of water from the leaf surfaces. Hence more understanding of bio-water saving which is by genetically manipulating stomatal density will certainly help to explain in detail these variations in stomatal density on leaf surfaces. Studies have shown that water deficit leads to an increase in stomatal density (Yang and Wang, 2001; Zhang and Zhang, 2007). This was the case with wheat stomatal density which always increases with continually increasing drought severity (Zhang et al., 2003). But it was not always the case in the present study where there were situations in which stomatal density was more in non-water deficit seedlings. Meanwhile, there were significant differences at $\mathrm{p}<0.05$ in stomatal density of seedlings watered with biweekly watering regimes.

Research reports have shown that the stomatal density and its index increase with water stress (Yang and Wang, 2001; Zhang and Zhang, 2007) but the number of stomata per leaf decrease (Quarrie and Jones, 1977). This was true for daily and weekly watering regimes where stomatal index was higher in weekly watering than in daily watering regimes. Subsequently percentage area covered by stomata on the leaf surfaces (i.e., stomatal index) was higher on the abaxial and adaxial leaf surfaces in $J$. gossypifolia and lower in C. indica. This means that there were more stomata occupying both leaf surfaces of the $J$. gossypifolia than in all other species (Table 4 and 5). Abdulrahaman and Oladele (2003) and Oyeleke et al. (2004) had earlier observed similar pattern of stomatal index on the abaxial and adaxial leaf surfaces of some vegetable species and some afforestation species, respectively.

Stomatal area or size was large in all the 3 species studied in all regimes and intervals of watering. Pataky (1969) had earlier classified those stomata with guard cell less than $15 \mu \mathrm{m}$ as small and those with guard cell more than $38 \mu \mathrm{m}$ as large. Those stomata that fall between these two ranges (15 and $38 \mu \mathrm{m})$ i.e., 16-37 $\mu \mathrm{m}$ can be described as moderate (Abdulrahaman, 2009). Stomatal size obviously decreased with water deficit as was also observed by other workers (Cutler et al., 1977; Quarrie and Jone, 1977; Spence et al., 1986; Xu and Zhou, 2008), indicating that this may enhance adaptation of plant to drought (Cutler et al., 1977; Spence et al., 1986; Martinez et al., 2007).

Bio-water saving is to increase water use efficiency of plants per unit of water input. Plant water use efficiency is determined by photosynthesis and transpiration, for both of which stomata are crucial (Wang et al., 2007; Zhang and Zhang, 2007). The rate of transpiration is directly related to the degree of stomatal opening and closing and to the evaporative demand of the atmosphere surrounding the leaf (The Columbia Encyclopedia, 2004). The leaf stoma is a pivotal gate controlling the exchange 
of $\mathrm{CO}_{2}$ and water vapour ( $\mathrm{Xu}$ and $\mathrm{Zhou}, 2008$ ). Thus, it was observed that stomata with high stomatal density and index and large stomatal size encouraged high transpiration rate as in the three mesophytic species studied here.

Occurrence of some higher transpiration rates in some seedlings of watering regimes of $J$. gossypifolia, $J$. curcas and C. indica were due to higher stomatal density and index in their leaves. The study of Oyeleke et al. (2004) and Abdulrahaman (2009) that high rate of transpiration occurs with high stomatal density and vice versa was highly supported in this work where low stomatal density and stomatal index gave low transpiration rate and high ones gave high transpiration rate (Table $3-5$ ).

The regulation of transpirational water loss is essential for terrestrial plant life. The differentiation between cuticular transpiration and residual stomatal transpiration represents a further step in order to understand plant response to water stress. The knowledge of the contribution of these parameters to the overall transpirational water loss may help to assess the ability of plants to withstand drought conditions with regard to adaptations to climate (Burghardt and Rieder, 2003).

\section{CONCLUSION}

Jatropha curcas is tolerant to water stress and can be maintained by watering regimes of $25-100 \mathrm{cc}$ per day, follow by $J$. gossypifolia which can be maintained by $200 \mathrm{cc}$ watering regime per day. Curcas indica needs high watering regime of $400 \mathrm{cc}$ per day for its maintenance.

\section{REFERENCES}

Abdulrahaman, A.A. and F.A. Oladele, 2003. Stomatal complex types, size, density and index in some vegetable species in Nigeria. Nig. J. Bot., 16: 144-150.

Abdulrahaman, A.A. and F.A. Oladele, 2008. Global warming and stomatal complex types. Ethnobotanical Leaflets, 12: 553-556.

Abdulrahaman, A.A., 2009. Morphological and epidermal adaptations to water stress in some ornamental plant species. Ph.D. Thesis, University of Ilorin, Ilorin, Nigeria.

Alves de Sena, J.O., H.A. Zaidan and P.R.C. Castro, 2007. Transpiration and stomatal resistance variations of perennial tropical crops under soil water availability conditions and water deficit. Brazilian Arch. Biol. Technol., 50: 225-230.
Awad, M. and P.R.C. Castro, 1992. Introducao a fisiologia vegetal. Sao Paulo, Nobel, pp: 177.

Bailey, N.T.J., 1995. Statistical Methods in Biology. Cambridge University Press, Cambridge, UK., pp: 255.

Balee, W.L., 1994. Footprints of the Forest: Ka'Apor Ethnobotany: The Historical Ecology of Plant Utilization by an Amazonian People. Columbia University Press, New York.

Buckley, T.N., 2005. The control of stomata by water balance. New Phytol., 168: 275-292.

Burghardt, M. and M. Rieder, 2003. Ecophysiological relevance of cuticular transpiration of deciduous and evergreen plants in relation to stomatal closure and leaf water potential. J. Environ. Biol., 54: 1941-1949.

Chaves, M.M. and M.M. Oliveira, 2004. Mechanisms underlying plant resilience to water deficits: Prospects for water-savings agriculture. J. Exp. Bot, 55: 2365-2384.

Cominelli, E., M. Galbiati, A. Vavasseur, L. Conti and T. Sala et al., 2005. Guard-cell-specific myb transcription factor regulates stomatal movements and plant drought tolerance. Curr. Biol., 15: 1196-1200.

Cutler, J.M., D.W. Rains and R.S. Loomis, 1977. The importance of cell size in the water relations of plants. Physiol. Plant., 40: 255-260.

Dai, Q., S. Peng, A.Q. Chavez and B.S. Vergara, 1995. Effects of UVB radiation on stomatal density and opening in rice (Oryza sativa L.). Ann. Bot., 76: $65-70$.

Davies, W.J. and J.S. Pereira, 1992. Spatial and Temporal Determinants: Crop Photosynthesis. In: Topics in Photosynthesis Ser., Baker, N.R. and H. Thomas (Eds.). Vol. 12. Elsevier, Amsterdam, pp: 213-233.

Dawson, T.E., 1993. Hydraulic lift and water use by plant: implications for water balance, performance and plant-plant interactions. Oecologia, 95: 565-574.

Dilcher, D.L., 1974. Approaches to the identification of angiosperm leaf remains. Bot. Rev., 40: 1-157.

Duncan, D.B., 1955. Multiple range and multiple F tests. Biometrics, 11: 1-42.

Dunford, N.T. and R.S. Vazquez, 2005. Effects of water stress on plant growth and thymol and carvacrol concentrations in Mexican oregano grown under controlled conditions. J. Applied Horticulture, 7: $20-22$.

Dutta, A.C., 2003. Botany for Degree Students. Revised 6th Edn., Oxford University Press, New Delhi, India, pp: 240 . 
Franco, C.M., 1939. Relation between chromosome number and stomata in Coffea. Botanical Gazette, 100: 817-827.

Gubitz, G.M., M. Mittelbach and M. Trabi, 1999. Exploitation of the tropical oil seed plant Jatropha curcas L. Bioresour. Technol., 67: 73-82.

Gudesblat, G.E., N.D. Iusem and P.C. Morris, 2007. Guard cell-specific inhibition of Arabidopsis MPK3 expression causes abnormal stomatal responses to abscisic acid and hydrogen peroxide. New Physiol., 173: 713-721.

Klooster, B. and E. Palmer-Young, 2004. Water stress marginally increase stomatal density in $E$. canadensis but not in $A$. geradii. Tillers, 5: 35-40.

Kouwenberg, L.L.R., W.M. Kurschner and J.C. McElwein, 2007. Stomatal frequency change over altitudinal gradients: Prospects for paleoaltimetry. Rev. Mineral. Geochem., 66: 215-241.

Larcher, W., 1980. Physiological Plant Ecology. 2nd Edn., Springer Verlag, Berlin, Hendelberg, pp: 303.

Lazaridou, M. and S.D. Koutroubas 2004. Drought effect on water use efficiency of berseem clover at various growth stages. 4th International Crop Science Congress (ICSC), Adelaide, South Australia. Poster Presentation. The Regional Institute Ltd.

Marti-nez, J.P., H. Silva, J.F. Ledent and M. Pinto, 2007. Effect of drought stress on the osmotic adjustment, cell wall elasticity and cell volume of six cultivars of common beans (Phaseolus vulgaris L.). Eur. J. Agron., 26: 30-38.

Metcalfe, C.R. and L. Chalk, 1988. Anatomy of Dicotyledons. 2nd Edn., Oxford University Press, USA., Oxford, pp: 97-177.

Metselaar, K. and Q.J. Lier, 2007. The shape of the transpiration reduction function under plant water stress. Vadose Zone J., 6: 124-139.

Morton, J.F., 1981. Atlas of Medicinal Plants of Middle America: Bahamas to Yucatan. Charles C. Thomas, Spring field, USA., pp: 1420.

Obiremi, E.O. and F.A. Oladele, 2001. Water-conserving stomatal systems in selected Citrus species. South Afr. J. Bot., 67: 258-260.

Oduola, T., G.O. Adeosun, T.A. Oduola, G.O. Avwioro and M.A. Oyeniyi, 2005. Mechanism of Jatropha gossypifolia stem latex as a haemostatic agent. Eur. J. Gen. Med., 24: 140-143.

Olowokudejo, J.D., 1993. Comparative epidermal morphology of West African species of Jatropha L. (Euphorbiaceae). Bot. J. Linnean Soc., 3: 139-154.
Openshaw, K., 2000. A review of Jatropha curcas: An oil plant of unfulfilled promise. Biomass Bioenergy, 19: 1-15.

Oudhia, P., 2001. Jatropha as medicinal herb in chhattisgarh, India: Natural occurrence, traditional medicinal knowledge and cultivation. Research Note, 2001. http:/www.botanical.com/site/column_poudhia /44_jatropha.html.

Oyeleke, M.O., A.A. Abdulrahaman and F.A. Oladele, 2004. Stomatal anatomy and transpiration rate in some afforestation tree species. NISEB J., 4: 83-90.

Pataky, S., 1969. Leaf Epidermis of Salix. In: Anatomy of the Dicotyledons, Vol. 1. 2nd Edn., Metcalfe, C.R. and L. Chalk (Ed.). Clarendon Press, Oxford, pp: 100 .

Pei, Z.M. and K. Kuchitsu, 2005. Early ABA signaling events in guard cells. J. Plant Growth Regulat, 24: $296-307$.

Philips, E.A., 1959. Methods of Vegetation Study. Holt Publishing Company, New York, USA., pp: 44.

Pramanik, K., 2003. Properties and use of Jatropha curcas oil and diesel fuel blends in compression ignition engine. Renewable Energy, 25: 239-248.

Qiang, L., Y. Long-jiang, D. Yang, L. Wei, L. Mao-tang and C. Jiang-hua, 2007. Leaf epidermal characters of Lonicera japonica and Lonicera confuse and their ecology adaptation. J. For. Res., 18: 103-108.

Quarrie, S.A. and H.G. Jones, 1977. Effects of abscisic acid and water stress on development and morphology of wheat. J. Exp. Bot., 28: 192-203.

Spence, R.D., H. Wu, P.J.H. Spharre and G. Clark, 1986. Water stress effects on guard cell anatomy and the mechanical advantage of the epidermal cells. Plant Cell Environ., 9: 197-202.

Tanner, W. and H. Beevers, 2001. Transpiration, a prerequisite for long-distance transport of minerals in plants?. Proc. Natl. Acad. Sci., 98: 9443-9447.

Tardieu, F., 1997. Genetical, Physiological and Molecular Biological Analysis. In: Drought Tolerance in Higher Plants, Belhassan, E. (Ed.). Kluwer Academic Publisher, The Netherlands, pp: 15-26.

The Columbia Encyclopedia, 2004. Transpiration. 6th Edn., Columbia University Press, Columbia.

Walter, H., 1979. Vegetation of the Earth and Ecological Systems of the Geo-Biosphere. 2nd Edn., Springerverlag, New York, pp: 18-21.

Wang, Y., X. Cheng and C.B. Xiang, 2007. Stomatal density and bio-water saving. J. Integrative Plant Biol., 49: 1435-1444. 
Wu, L., P. De Reffge, B.G. Hu, F.X. Le Dimet and P.H. Couurnede, 2005. A water supply optimization problem for plant growth based on greenlab model. Revue ARIMA, 4: 194-207.

Xu, Z.Z. and G.S. Zhou, 2008. Responses of leaf stomatal density to water status and its relationship with photosynthesis in a grass. J. Exp. Bot., 59: 3317-3325.

Yang, H.M. and G.X. Wang, 2001. Leaf stomatal densities and distribution in Triticum aestivum under drought and $\mathrm{CO}_{2}$ enrichment. Acta Phytoecol. Sinica, 25: $312-316$.
Zhang, X.Y., H.M. Wang, Z.D. Hou and G.X. Wang, 2003. Stomatal density and distributions of spring wheat leaves under different planting densities and soil moisture levels. Acta Phytoecol. Sinica, 27: 133-136.

Zhang, Z.B. and J. Zhang, 2007. Water saving agriculture: An urgent issue. J. Integrative Plant Biol., 49: 1409-1409. 